\title{
XРОНИKA
}

\section{СЕМИНАР И КОНФЕРЕНЦИЯ ПО ФИЗИКЕ И ПРИМЕНЕНИЮ УОТРАЗВУКА}

С 23 по 26 слтября 1957 г. в .Тенин-

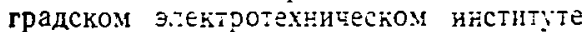
им. В. И. У.лявсза ı.Јенина) проходи. семинар по Физ:̈е и применению утьтазвука, посьйе:ный памяти вьдаюімегося советского үеного физика ч.генакорреспондента АН СССР профессора Сергея Яков.тевича Соколова.

Семинар бы. организован кафедрой электроакустини .ТЭТИ. В его работе приняло участие более 100 ученых и ин. женеров Москвы, Ленинграда и другіх городов страны.

Работа семинара открылась встппительным словом заместителя директора института $\Gamma$. В. Одинцова, указавшего на выдаюшуюся роль профессора С. Я. Соколова в развитии ультраакустики н ее технических применений.

С подробным докладом о жизни н научной деятельности С. Я. Соколова вы. ступила его дочь - Е. С. Соколова.

Методам научной работы С. Я. Cokoлова и личным воспоминаниям о нем были посвящены зачитанные на семинаре письма Л. Л. Мясникова и С. Н. Ржев. кина.

Значительная часть сделанных на семинаре специальных докладов была посвящена вопросам ультразвукоскопии области технического применения ультразвука, созданной С. Я. Соколовым.

В совместном докладе Л. Г. Мерку.лова, Н. А. Евдокимова и А. С. Го.уубева «Ультразвуновые методы исследования твердых тел» были охарактеризованы достижения профессора С. Я. Соколова и его школы в разработке методов и алпа ратуры ультразвуковой дефектоскопии и микроскопин.

Большое внимание было уделено вопросу о применении ультразвуковых методов для изучения физических свойств и структуры твердых тел.

Доклад В. В. Богородского бы. посвящен применению ультразвука д.ля нзучения упругих и прочностных характеристик льдов, а доклад Н. В. Защука ультразвуковым методам исследования бетона.

Доклад А. К. Гурвича «Дальнейшие пути развития ультразвуковой аппарату. ры для контроля качества сварных соединений» познакомил участников семинара c результатами разработки аппаратуры
I.7я автоматической записи контроля сварных соединений.

Б. Н. Машарский сообщил о результағах проведенных им исследований по определению ультразвуковым методом характера дефектов.

Значительное место в работе семинара бь:ло отведено проблеме ультразвукового видения.

В докладе В. Г. Прохорова «О преобразовании ультразвукового изображения в видимое» бы.ти рассмотрены основные фнзические процессы в электронно-акустнческом преобразователе ультразвуковото sикроскопа.

П. В. Пономарев доложил об установке z.я у.льтразвукового видения, в которон. используется механическое сканироЕан)е изображения.

Pás[ejáb山ей способности при акусти„с-б-тичесом преоб́разовании методом

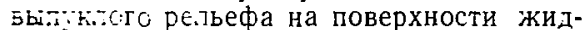
эсстін бы. посвящен доклад Е. Д. Пигу$\therefore$ escroro.

Iругсе важное направление работы! семннара было связано с ультразвуковыж: методами исследования жидких сред i! гоитиеского состояния вешества.

Дскитад Б. Б. Кудрявцева «Пути исгользования ультраакустических измере:н в физнко-химических исследованиях» гаса.тся анализа основных трудностей гр! объяснении поглошения ультразвука в жидкостях. С. А. Балян сообщила о усс.ледовании распространения ультразвука в реагирующих жидкостях. Доклад В. Ф. Ноздрева касался новых результатов, полученных при исследовании поглощения ультразвука в ацетатах и других соединениях, где обнаружено наличие нескольких релаксационных областей.

Два доклада касались дальнейшего изучения воздействия ультразвука на процессы кристаллизации.

И. И. Теумин сообщил о влиянии упругих колебаний на кристаллизацию и технологические свойства металлов и сплавов, Х. С. Багдасаров - о результатах исследований воздействия ультразвука на кинетику процесса кристаллизации.

Ряд докладов, заслушанных на семинаре, касался методики измерений скорости и поглощения ультразвука.

К такнм докладам относились: совмест. ный доклад В. Ф. Ноздрева, В. Ф. Яков- 
лева, Н. И. Қошкина - «Развитие идей прсфессора С. Я. Соколова по импульсной технике в лаборатории МОПИ»; доклад И. Г. Михайлова - «Применение пиезокварцевого клина для измерения поглощения в жидкостях»; доклад В. А. Соловьева - «Применение составного пьезоэлектрического вибратора для исследования полимеров»; доклад $Г . \mathrm{H}$. Феофанова - «Нзмерение скорости распространения ультразвуковых волн в жидкостях методом импульсного интерферометра».

С 3 по 7 февраля 1958 г. в Московском областном педагогическом институте им. Н. К. Қрупской состоялась 6-я научная конференция по применению ультраакустики к исследованию вещества.

В работе конференции приняло участие большое количество научных работников из различных городов Советского Союза (Москвы, Ленинграда, Қалинина, Горького, Еревана, Каунаса и др.). На конференции присутствовали также иностранные ученые.

Конференция открылась докладом В. Ф. Ноздрева «Некоторые новые проблемы исследования критического состояния акустическими методами» (к итогам работы Международного коллоквиума 1957 г. в Париже). В докладе было доложено о весьма интересных результатах исследования критического состояния вещества ультраакустическим методом и о современном состоянии этого вопроса. Эти исследования представляют принципиальный интерес для выяснения молекулярного механизма релаксационных процессов в жидкостях.

На пленарных заседаниях были также заслушаны весьма интересные доклады Б. Б. Кудрявцева «Распространение звука в жидкостях», Н. Н. Акулова «Дисперсия ультразвука в ферромагнетиках», А. С. Предводителева «О распространении и поглощении звуковых волн в коллоидных растворах», А. К. Зарембо «Поглощение ультразвуковых волн конечной амплитуды и ряд других.

На конференции работало пять секций.

На секции молекулярной акустики ма. лых амплитуд большинство заслушанных докладов и сообщений касалось результатов по измерению поглошения ультразвука в различных жидкостях.

Следует отметить совместный доклад Н. И. Кошкина, В. С. Лутовинина, В. $\Phi$. Ноздрева и О. А. Старостиной «Комплексное исследование этилацетата оптическим и нмпульсным методами в широком интервале температур и давле. ний», И. Г. Михайлова «О поглощении ультразвуковых волн в этилацетате», Л. Г. Белинской «Исследование поглоще. ния ультразвука в этилацетате на высоних частотах», Б. И. Кальянова «Измерение поглощения ультразвуковых волн в критической области метилацетата»,
О. А. Старостиной «Исследование поглощения ультразвуковых волн в пропилацетате оптическим методом».

Всего на заседании секции было заслушано около 25 докладов.

На секции молекулярной акустики конечных амплитуд было заслушано шесть докладов и сообщений. Среди них доклад А. П. Капустина и В. Е. Кавалюнайте «Рост и растворение монокристаллов в ультразвуковом поле», А. Н. Трофимова «Распределение металла на поверхности катода при электроосаждении меди в ультразвуковом поле» и другие.

$\mathrm{Ha}$ секции промышленного применения ультразвука было представлено 12 докладов и сообщений. Интерес вызвали сообшения Б. Б. Кудрявцева «О диспергирующем действии кавитации», В. Н. Скоробогатова «О исследованин электрнческих разрядов при кавитации», Л. Ф. Лепендина «О перспективах использования ультразвука для улучшения шва при электрошлаковой сварке», А. И. Золотовой «Влияние ультразвуковых колебаний на пищевые продукты растительного происхождения».

На секции распространения ультразвука в твердых телах был заслушан совместный доклад Л. Г. Меркулова и Е. С. Соколовой, посвященный исследованию механизма поглощения ультразвуковых волн в монокристаллах кварца в широком диапазоне частот вплоть до 600 мг2ц. Б. Б. Кудрявцев рассказал о влиянии ультразвука на люминесценцию фосфоров. И. В. Бушуев сообщил о исследовании по измерению скорости и поллощения ультразвука в керамике титаната бария.

На секции акустических методов исследования был представлен интересный доклад С. Н. Ржевкина по теории ультразвукового интерферометра. Сообщение Ю. С. Трелина было посвящено ультразвуковому интерферометру для измерения скорости ультразвука в жидкостях для температур до $200^{\circ} \mathrm{C}$. И. Н. Ермолов сообщил о результатах по исследованию зависимости амплитуды эхо-сигнала им. пульсного ультразвукового дефектоскопа от расположения и размеров плоского отражателя.

В общей сложности на конференции бъ̆ло заслушано более 70 докладов и сообщений.

Заслушанные доклады и научная дискуссия по ним наглядно продемонстрировали широту фронта работ, проводимых различными лабораториями.

Можно надеяться, что прошедшие семинар и конференция будут способство. вать дальнейшему развитню работ в области ультраакустики и ее практических приложений.

Труды семинара и конференции предполагается опубликовать отдельными изданиями. 